\title{
Analysis of H/V Ratio Curve to Estimate Seismic Hazard Vulnerability in Lombok Island, West Nusa Tenggara, Indonesia
}

\author{
Harsuko, M.R.C. ${ }^{1}$, Zulfakriza, Z. ${ }^{2,3 *}$, Nugraha, A. D. ${ }^{2,3}$, Muzli, M. ${ }^{4}$, Sahara, D.P. ${ }^{2,3}$ \\ Puspito, N.T. ${ }^{2,3}$, Husni, Y.M. ${ }^{1}$, Prabowo B.S. ${ }^{1}$, Sarjan, A.F.N. ${ }^{1}$ \\ ${ }^{1}$ Geophysical Engineering Program, Faculty of Mining and Petroleum Engineering, ITB, Indonesia \\ ${ }^{2}$ Global Geophysics Research Group, Faculty of Mining and Petroleum Engineering, ITB, Indonesia \\ ${ }^{3}$ Center for Earthquake Science and Technology, ITB, Indonesia, \\ ${ }^{4}$ Indonesian Meteorological, Climatological, and Geophysical Agency, Jakarta, Indonesia, \\ *Email: zulfakriza@itb.ac.id
}

Submit: 2020-06-09; Revised: 2020-08-01; Accepted: 2020-08-14

\begin{abstract}
In 2018, Lombok Island was hit by a series of destructive earthquakes. According to Indonesian Meteorological, Climatological, and Geophysical Agency data, about 1,973 felt earthquakes $(\mathrm{M}>3)$ which shaken Lombok were recorded during August 2018 with three earthquakes with the largest magnitude of $6.9 \mathrm{Mw}, 6.8 \mathrm{Mw}$, and 6.2 Mw. National Board for Disaster Management reported about 555 deaths, 1,833 people injured, and 186,010 houses damaged as a result of Lombok earthquake on August 5th, 2018. A number of seismometers were placed on Lombok Island from August 3rd, 2018 to October 19th, 2018 to monitor the aftershock events. There are 17 stations that record seismicity in Lombok consisting of 10 broadband sensors and 7 short period sensors. In this study, we used the Horizontal-to-Vertical Spectral Ratio (HVSR) method to analyze the risk of earthquake in the Lombok region. The basic concept of this method is to do a comparison between the horizontal component spectrum and the vertical component spectrum of a wave, where theoretically the particle movement of the horizontal component is greater than the particle movement of the vertical component on soft ground, whereas on the hard ground both components (horizontal and vertical) will be similar. H/V curve obtained from earthquake recordings (Earthquake Horizontal-to-Vertical Ratio/EHVR) and $\mathrm{H} / \mathrm{V}$ curve obtained from microtremor recordings (Microtremor Horizontal-to-Vertical Ratio/MHVR) shows good agreement and high correlation. Empirical correction of EMR (Earthquake-to-Microtremor Ratio) managed to decrease the difference of estimation of predominant frequency and amplification factor between EHVR and MHVR. Predominant frequency, amplification, and seismic vulnerability map agree with the geological condition of Lombok Island, where high value of amplification and seismic vulnerability was found on soft and thick ground. This study conclude that the maximum ground acceleration and the construction of the building should also considered when one wants to investigate the effect of an earthquake to the damage occurred, beside the site effects. Keywords: earthquake amplification, HVSR method, Lombok earth-
\end{abstract}

quake, predominant frequency, seismic vulnerability

\section{INTRODUCTION}

Lombok Island is an island in the West Nusa Tenggara region, Indonesia with a population of $3,474,247$ inhabitants. Lombok is also one of the tourism destinations in Indonesia with an average visitor of 1.7 million per year. In 2018, Lombok was shaken by a series of destructive earthquakes. According to data from the Indonesian Meteorological, Climatological and Geophysical Agency (BMKG), about 1,973 felt earthquakes $(\mathrm{M}>3$ ) which shaken Lombok were recorded during August 2018 with three earthquakes with the largest magnitude of $6.9 \mathrm{Mw}, 6.8 \mathrm{Mw}$, and $6.2 \mathrm{Mw}$. National Board for Disaster Management (BNPB) recorded about 555 deaths, 1,833 people injured, and 186,010 houses damaged as a result of Lombok earthquake on August 5th, 2018. The worst damage caused by the Lombok earthquake in July-August 2018 occurred in the north of Lombok, reaching VIII-IX MMI, while the southern region suffered less damage (BMKG, 2018).

Based on the above description, it is necessary to assess the earthquake risk and seismic hazard on Lombok Island. The method used in this study is Horizontal-to-Vertical Spectral Ratio (HVSR). The method is used to produce a distribution predominant frequency map, earthquake amplification map, and seismic vulnerability map. All maps produced are expected to support understand the effects of the Lombok earthquake to the occurred damage.

\section{GEOLOGICAL SETTING}

According to Foden and Varne (1980), Lombok Island is part of the Sunda-Banda arc system. The Banda Arc forms a tectonic buffer zone at the boundary of three tectonic plates, Indo-Australian, Pacific and Eurasian plates in the east (Harris, 2011). This area consists of a complex arrangement between island arcs, marginal basins, continental frag- 




Gambar 1. Geological map of Lombok Island (modified from Wafid et al., 2014).

ments, and ophiolites that combine in the evolution of plate boundaries that have been repeated over the past 200 million years (Hamilton, 1979). This complex tectonic condition influences geological structures, especially faults, which form around the island of Lombok. There are four active faults that surround Lombok Island, namely the Flores fault in the north, the Indo-Australian subduction in the south, the strike-slip fault of the Lombok Strait in the west, and the strike-slip fault of the Sumbawa Strait in the east (Irsyam et al., 2017).

The geological investigation was conducted by Wafid et al (2014) obtained that there were seven rock groups on the island of Lombok, namely alluvium deposits groups, inseparable volcanic rock groups, pumice tuff groups, breccia and lava groups, limestone groups, sandstone groups, and igneous rock groups. The northern part of Lombok Island is dominated by inseparable volcanic rock groups, while in the southern part of Lombok Island is dominated by breccia and lava groups. There are accumulations of alluvium deposits in the western (the vicinity of Mataram City) and eastern part of Lombok Island (see Figure 1).

\section{DATA AND METHODS}

We extract data seismic from 17 temporary stations across Lombok Island which the station distribution can be seen in Figure 2. The seismometer used consisted of 10 broadband sensors and 7 short period sensors. Recording is carried out from August 3rd, 2018 to October 19th, 2018, but not all stations operate during this period.

Before processing, instrument correction was applied on the recording data measured by seismometers to eliminate the effects of the instrument. Data is processed using Geopsy software to produce HVSR curves. On the HVSR curve produced, empirical correction namely EMR (Earthquaketo-Microtremor Ratio) was applied. The value of the predominant frequency and amplification factor of each station can be obtained through the HVSR curve. After that, the seismic vulnerability index can be calculated from the values of the predominant frequency and amplification factors obtained. Predominant frequency, amplification factor, and seismic vulnerability index are then mapped using Generic Mapping Tools (GMT) software.

The $\mathrm{H} / \mathrm{V}$ curve from microtremor (Microtremor Horizontal-to-Vertical Ratio/MHVR) and the $\mathrm{H} / \mathrm{V}$ curve



Gambar 2. Temporary seismic station location map on Lombok Island.

from earthquake record (Earthquake Horizontal-to-Vertical Ratio/EHVR) will be compared, so two sets of parameters of STA/LTA (Short Time Average / Long Time Average) are determined. To extract micro-tremor signals, the selected length of time window is 150 seconds, the selected range of STA/LTA value is $0.2-1.2$, and the selected time span of observation is 13.00-21.00 UTC (21.00-05.00 local time). To extract earthquake signals, the selected length of time window is 50 seconds, the selected range of STA/LTA value is $2.0-5.0$, and the observation time span is set to one day (24 hours).

To perform EMR correction, the resulting $\mathrm{H} / \mathrm{V}$ curve must be grouped according to its predominant frequency because the predominant frequency reflects the amplification characteristics of a site (Kawase, 2018). Therefore, the H/V curve in this study is grouped into five categories: Category $\mathrm{I}$ is the $\mathrm{H} / \mathrm{V}$ curve with the predominant frequency (F0) in the range of 0.2-1 Hz; Category II is the $\mathrm{H} / \mathrm{V}$ curve with $\mathrm{F} 0$ in the range of 1-2 Hz; Category III is the $\mathrm{H} / \mathrm{V}$ curve with $\mathrm{F} 0$ in the range of $2-5 \mathrm{~Hz}$, and; Category IV is the $\mathrm{H} / \mathrm{V}$ curve with $\mathrm{F} 0$ in the range of $5-10 \mathrm{~Hz}$.

The next step is to calculate the EMR at each station by dividing the EHVR curve with the MHVR curve on that station. The EMR curve in each category can then be obtained by averaging the EMR curve of all stations in that category. Finally, the transformation of MHVR to pseudoEHVR (pEHVR) was done by multiplying the MHVR curve with the average EMR curve in the corresponding category.

The average EMR curve for each category can be seen in Figure 3. From the graph, it can be seen clearly that the normalization frequency range decreases as F0 increases. The graph does not show the average EMR curve in Category I, because the $\mathrm{H} / \mathrm{V}$ curve included in that category is only one curve. 


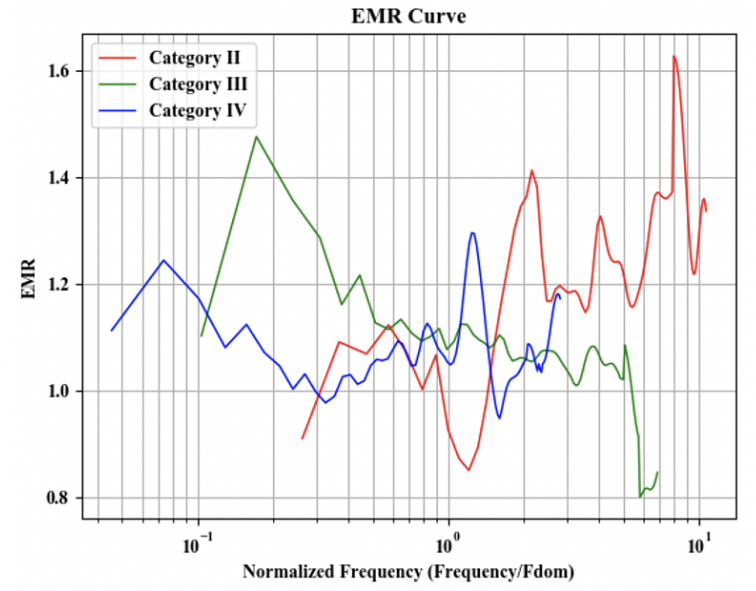

Gambar 3. EMR curve on every category.

\section{RESULTS AND DISCUSSIONS}

\subsection{MHVR Curves and EHVR Curves}

The resulting MHVR and EHVR curves are displayed in one graph at each station. Example of the MHVR and EHVR curve is shown in Figure 4, where the red line is the MHVR curve and the blue dotted line is the EHVR curve. The number in the lower right corner is the correlation coefficient value between the two curves.

Qualitatively, the trend of the MHVR curve with the EHVR curve corresponds to each other. Outside the predominant frequency range of the $\mathrm{H} / \mathrm{V}$ curve, at some stations there are local peaks on the EHVR curve that is not observed on the MHVR curve. This can occur due to different nature of the wave field of microtremors and earthquakes (Kawase, 2018).

The correlation between the predominant frequency (F0) of the MHVR curves and F0 of the EHVR curves is shown in Figure 5, while the correlation between $\mathrm{H} / \mathrm{V}$ amplitude at F0 (A0) of the MHVR curves and A0 of the EHVR curves is shown in Figure 6. The red line shows perfect correlation $(=1)$. The two figures show that $\mathrm{F} 0$ and $\mathrm{A} 0$ from the MHVR curves and EHVR curves correspond to each other, even the correlation is almost perfect (close to 1). However, A0 from the MHVR curves tends to underestimate A0 from the EHVR curves. These are in accordance with previous studies (Kawase, 2018; Mucciarelli, 2003; Satoh et al., 2001).

\subsection{EMR Correction and pEHVR Curves}

After the average EMR curve in each category is obtained, EMR correction is applied to the MHVR curve to obtain the pEHVR curve. Example of EMR correction is shown in Figure 7. Significant changes are seen in LOM02, LOM03, LOM07, and LOM17 where the amplitude of pEHVR curve, especially in the frequency range around F0, resembles the EHVR curve's more.

After correction of EMR on the MHVR curve, it can be seen that there is a quite significant increase in the correlation coefficient value at some stations whose correlation coefficient value is not high enough (i 0.9 ), namely at LOM03 and LOM17. Meanwhile, the value of the H/V curve corre-

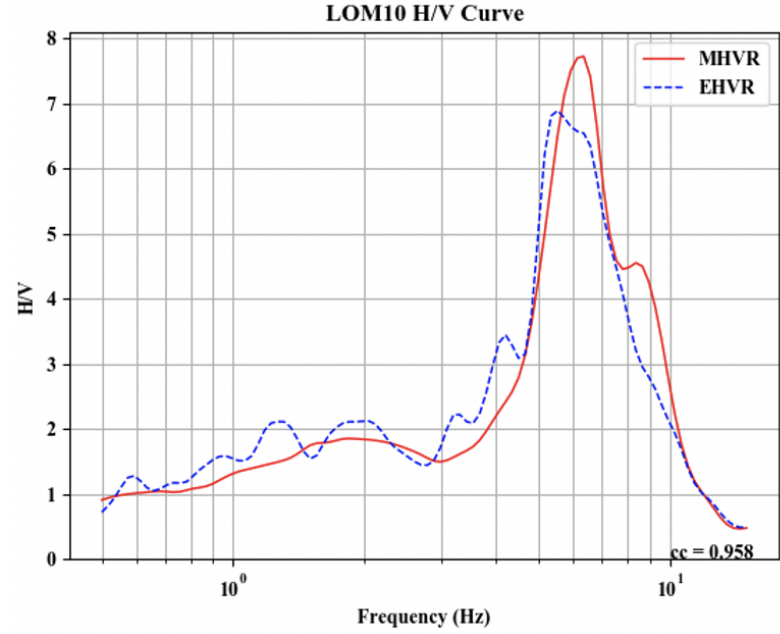

Gambar 4. Example of resulting MHVR and EHVR curve on LOM10 station.

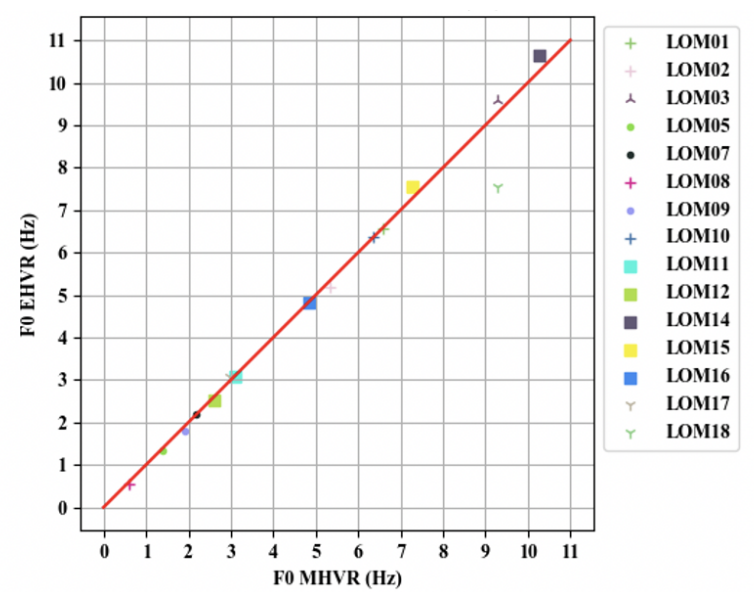

Gambar 5. Example of resulting MHVR and EHVR curve on LOM10 station.

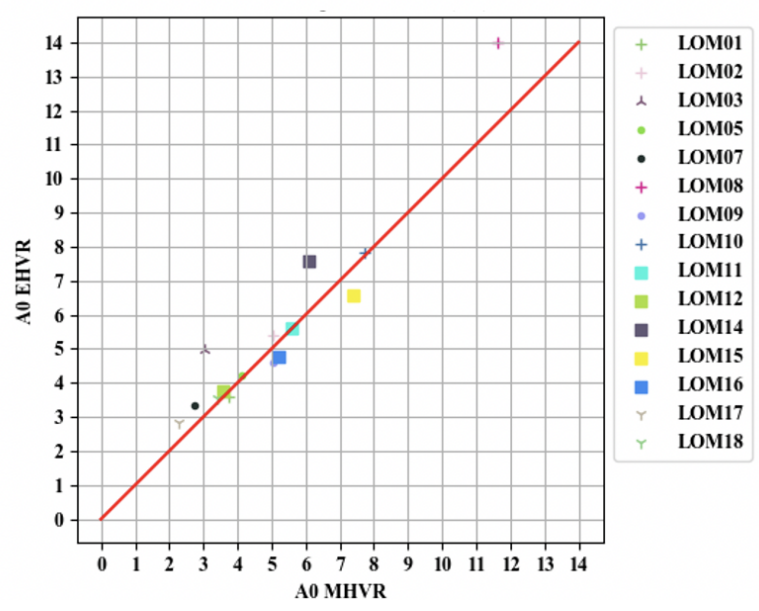

Gambar 6. Example of resulting MHVR and EHVR curve on LOM10 station. 

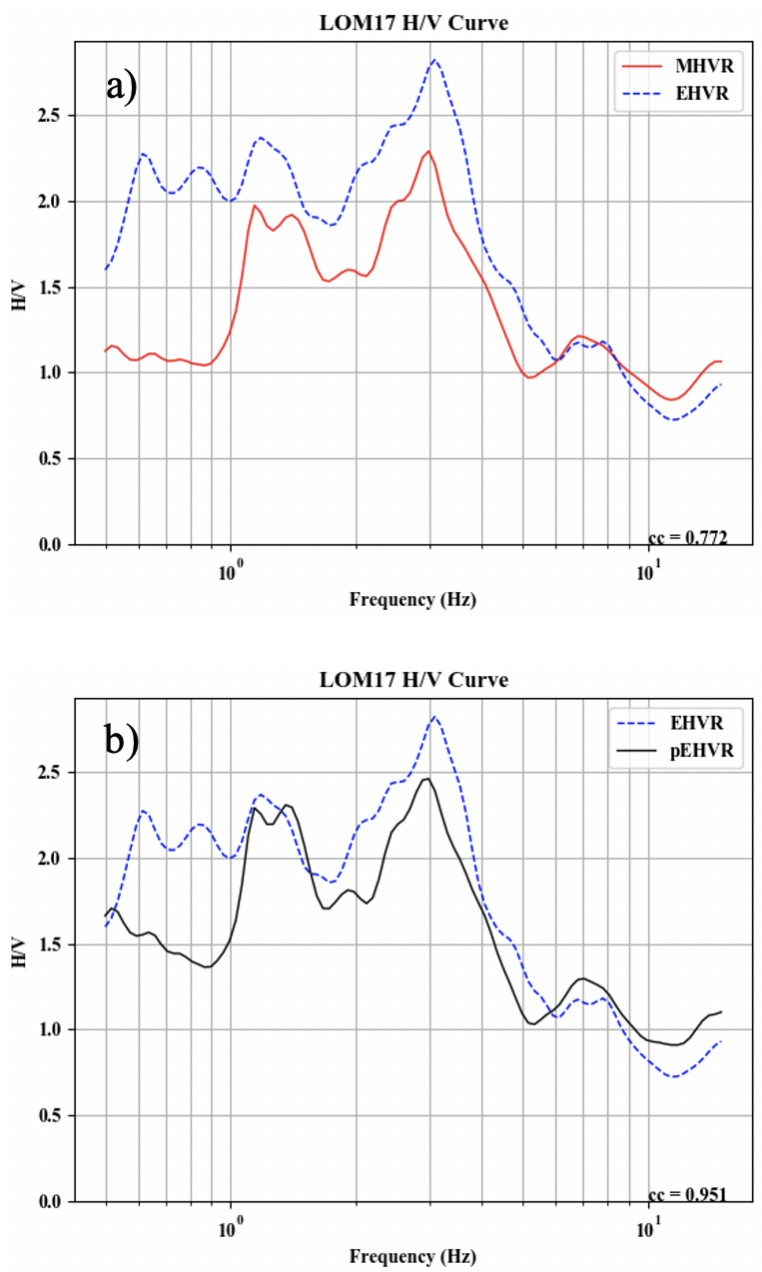

Gambar 7. Example of resulting MHVR and EHVR curve on LOM10 station.

lation coefficient at other stations remains at a high value $(>0.9)$. This shows that EMR correction can help increase the correlation coefficient value on several stations with a correlation coefficient value that is not high enough, without significantly affecting the correlation coefficient value at other stations.

In addition, the estimation of the predominant frequency value and amplification using the MHVR curves, EHVR curves, and pEHVR curves are also compared, whose values can be seen in Table 2. RMS (Root-Mean-Square) difference between A0 obtained from MHVR curves and A0 from EHVR curves is 0.951 , while the RMS difference between A0 obtained from the MHVR curves and A0 from $\mathrm{pE}-$ HVR curves is 0.921 . There was an improvement (decrease in RMS difference value) of $3.21 \%$. For the predominant frequency, the RMS difference between F0 obtained from MHVR curves and F0 from EHVR curves is 0.49, while the RMS difference between F0 obtained from MHVR curves and F0 from pEHVR curves is 0.41 . There was an improvement (decrease in RMS difference value) of $15.32 \%$.

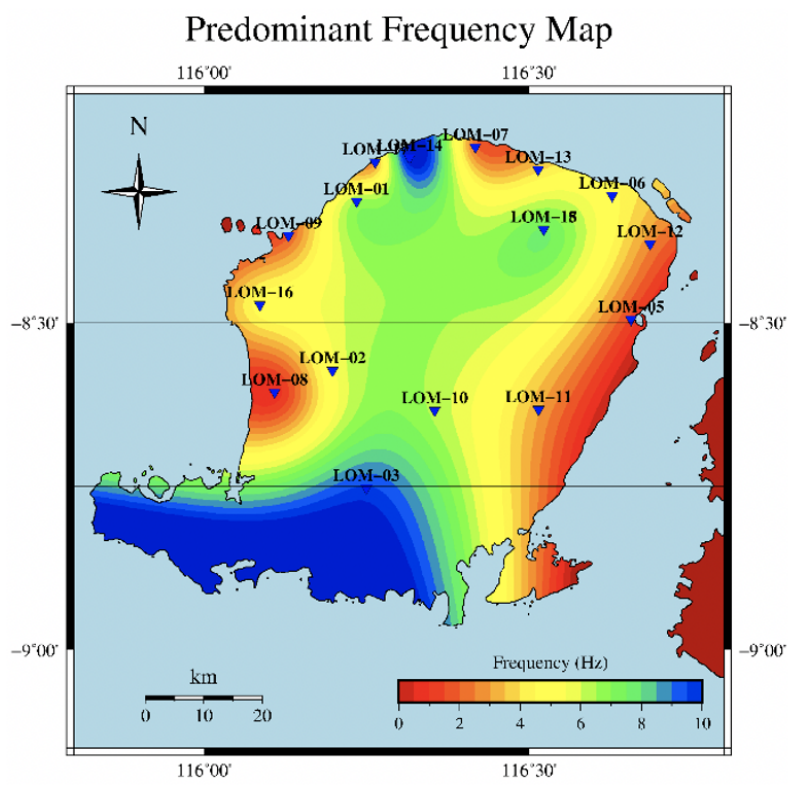

Gambar 8. Predominant frequency map on Lombok Island.

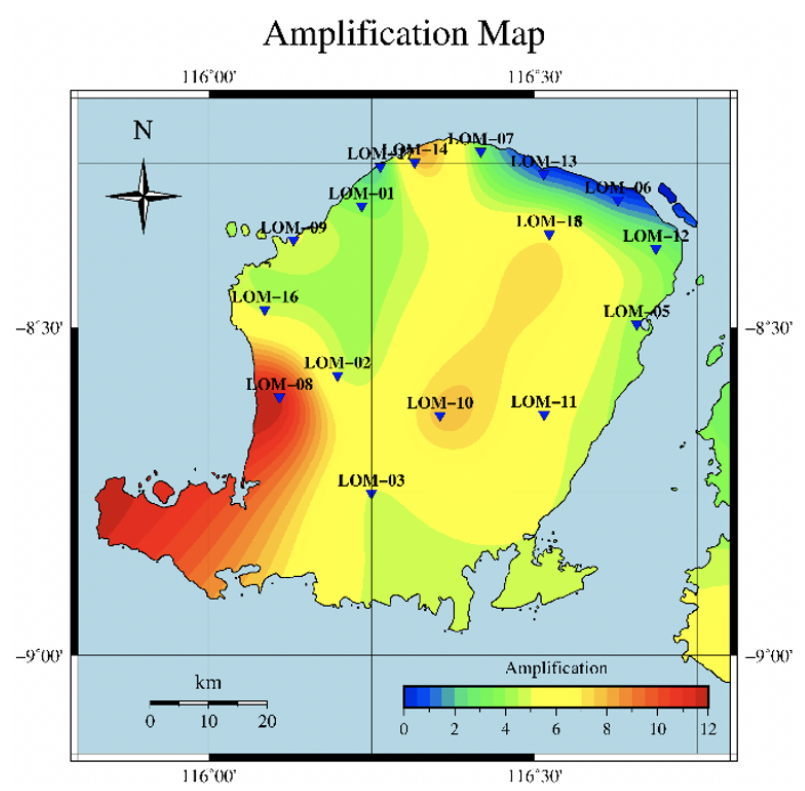

Gambar 9. Amplification map on Lombok Island.

\subsection{Predominant Frequency, Amplification Factor, and Seismic Vulnerability Index}

The predominant frequency and amplification factor at each station from the pEHVR curves are then mapped to see the distribution of the values. The predominant frequency map is shown in Figure 8 and the amplification map is shown in Figure 9. Bicubic interpolation is used to produce the map.

On the resulting predominant frequency map, there appears to be a low predominant frequency value in the eastern, western, and northwest regions of Lombok Island, while in the southern region it is dominated by a high predominant frequency value. The predominant frequency can be 


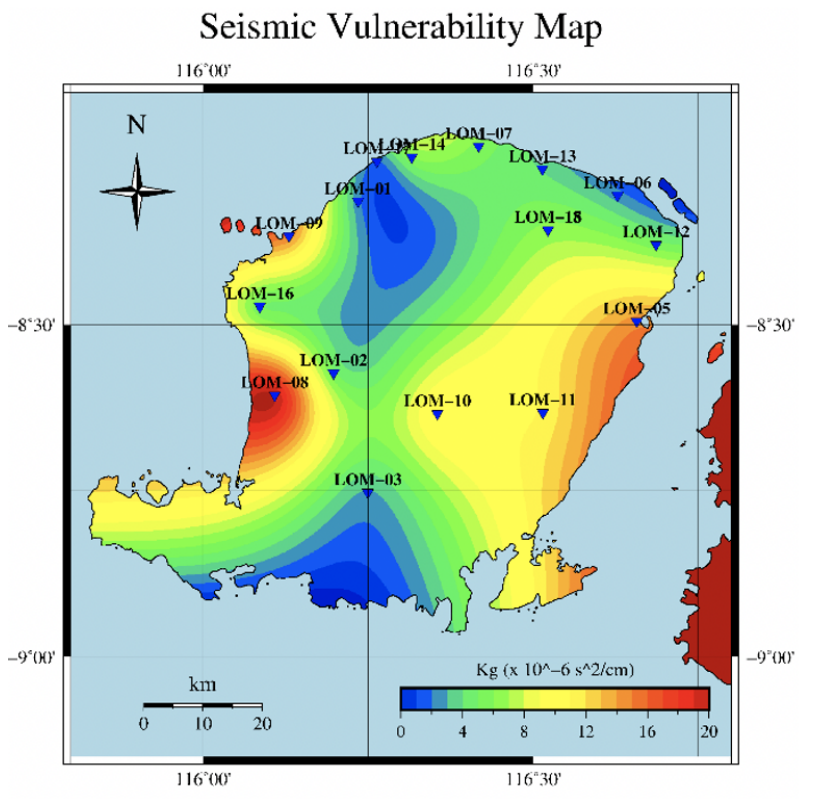

Gambar 10. Seismic vulnerability (Kg) map on Lombok Island.

related to the depth of the basement layer according to the equation proposed by Nakamura (2008):

$$
F_{o}=\frac{C_{s}}{(4 h)}
$$

Where Cs is the velocity of the $\mathrm{S}$ wave on the surface and $\mathrm{h}$ is the depth of the basement layer. Thus, a low predominant frequency value can be interpreted as a thick sediment. This is in accordance with the resume of the results of the Lombok Island geological engineering mapping by Wafid et al. (2014) that in the eastern and western regions of Lombok Island are alluvium deposits with larger average thickness than other rock groups.

Amplification map can provide an overview of impedance contrast below the surface. On the amplification map, a high amplification value was observed in the western part of Lombok Island, while in the central part of Lombok Island dominated by moderate value and in the north tended to be small value. A high amplification value can be caused by a soft layer or weathered rocks overlying harder layer (Bard, 2004).

The seismic vulnerability index $(\mathrm{Kg})$ can be estimated through the following equation after the predominant frequency and amplification values are known (Nakamura, 2008). The $e$ parameter is assumed to be $60 \%$, while the value of $\mathrm{Cb}$ ( $\mathrm{S}$ wave velocity in the basement) is obtained from the $1 \mathrm{D}$ velocity model of Crust 1.0 which is $550 \mathrm{~m} / \mathrm{s}$. Map of the seismic vulnerability index $(\mathrm{Kg})$ distribution is shown in Figure 10.

The seismic vulnerability map shows that there are high values in the eastern, western, and northwestern regions of Lombok Island, while in the northern and southern regions it is dominated by low seismic vulnerability values. Like the predominant frequency map, this map is in accordance with the geological conditions on the island of Lombok where there are alluvium deposits in the east, west and northwest

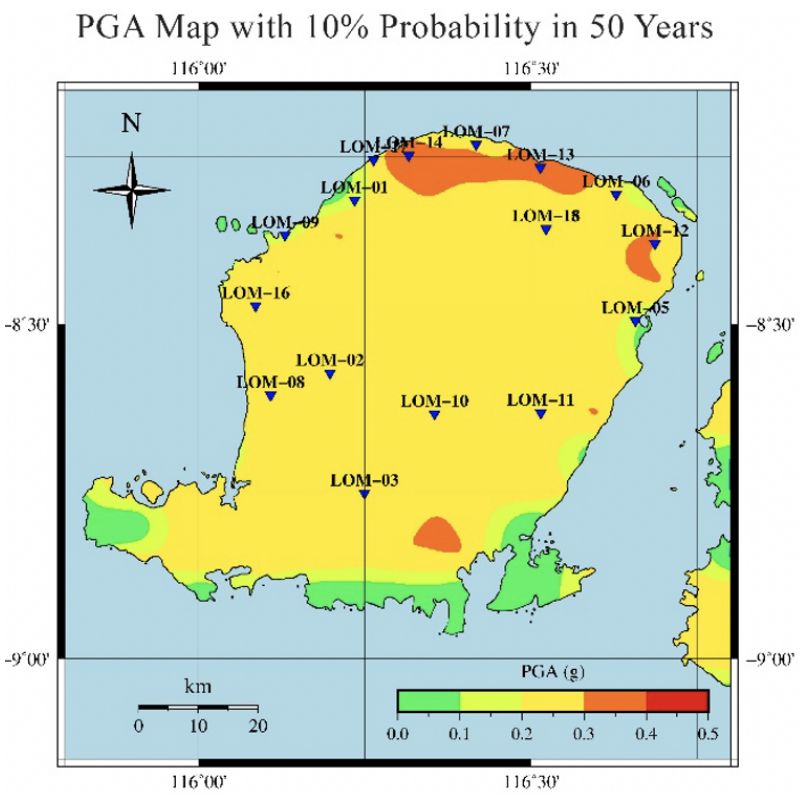

Gambar 11. PGA map on Lombok Island with $10 \%$ probability in 50 years (modified from Irsyam et al., 2017)

regions which are pictured by high seismic vulnerability index. Effective strain on the soil can be estimated by multiplying the value of $\mathrm{Kg}$ with maximum acceleration in the basement (Nakamura, 2008).

Referring to Table 1 and data from BMKG, the worst damage caused by the Lombok earthquake in 2018 occurred in North Lombok Regency, especially in the northwest region of Lombok Island. The seismic vulnerability map also shows that there are regions with high $\mathrm{Kg}$ in the northwest. Even so, the seismic vulnerability map shows that the northern region of Lombok Island is dominated by a low $\mathrm{Kg}$ value. The western and eastern regions (Mataram City and East Lombok Regency) with high amplification and seismic vulnerability value, the observed damage is not as severe as the damage in the northern region.

Some discrepancies between the map of predominant frequency, amplification, and seismic vulnerability with the occurred damage indicate that there are other factors that affect damage to the surface, in addition to the site effect. One factor is the maximum ground acceleration (PGA) observed on the surface. Figure 11 shows PGA maps on Lombok Island with a $10 \%$ probability in 50 years modified from Irsyam et al. (2017). On the map it can be seen that the northern region of Lombok Island has the highest PGA value compared to other regions.

Another factor to consider is building construction. Buildings that have the same frequency as the frequency of soil characteristics below will experience resonance and have tendency to experience more severe damage (Mucciarelli, 1999). In addition, other things related to building construction also need to be considered, such as materials used, reinforcement, and so on. 


\section{CONCLUSIONS}

MHVR curves with EHVR curves has a good correlation, where in general the trends of the two curves corresponds to each other. The predominant frequency value obtained from the MHVR curve with the EHVR curve also corresponds. However, the value of the MHVR H/V amplitude (amplification) tends to underestimate the value of the EHVR H/V amplitude. EMR correction can help increase the correlation coefficient value on several stations with a correlation coefficient value that is not high enough, without significantly affecting the correlation coefficient value at other stations. From the experiment results, there was a decrease in the RMS difference value of the predominant frequency and amplitude of $\mathrm{H} / \mathrm{V}$ by applying the EMR correction to MHVR.

The map of the predominant frequency, amplification, and seismic vulnerability produced in general is in accordance with the geological conditions on the island of Lombok, which the high seismic vulnerability index was observed in the alluvium region because it is a soft soil and has a large thickness. The existence of some discrepancies between the map of predominant frequency, amplification, and seismic vulnerability with the observed damage indicates that there are other factors that affect damage to the surface in addition to the site effect, namely maximum ground acceleration and building construction.

\section{REFERENCES}

Alihudien, A. dan Manggala, A. S. (2015): Analisa Amplifikasi Dan Frekwensi Natural Tanah Setempat Dalam Pembuatan Mikrozonasi Gempa Bumi (Studi Kasus Kecamatan Sumbersari, Kabupaten Jember), International Conference of Indonesian Society of Remote Sensing.

Bard, P. (2004): Guidelines for The Implementation Of The H/V Spectral Ratio Technique On Ambient Vibrations Measurements, Processing And Interpretation, Site Effects Assessment Using Ambient Excitations (SESAME) European Research Project.

Foden, J.D., Varne, R. (1980): The Petrology and Tectonic Setting Of Quaternary- Recent Volcanic Centres Of Lombok And Sumbawa, Sunda Arc, Chemical Geology, 30, 201-226.

Hamilton, W. (1988): Plate tectonics and island arcs, Geol. Soc. Am. Bull., 100, 1503- 1527.

Hamilton, W.B. (1979): Tectonics of the Indonesian Region, US Govt., no. 1078,

Harris, R. (2011): The nature of the Banda Arc-Continent collision in the Timor Region, In: Brown D, Ryan PD (eds) Arccontinent collision, 163-211.

Havskov, J., Ottemöller, L. (2010): Routine Data Processing in Earthquake Seismology, Springer, United Kingdom.

Irsyam, M., Widiyantoro, S., Natawidjaja, D. H., Meilano, I., Rudyanto, A., Hidayati, S., Triyoso, W., Hanifa, N. R., Djarwadi, D., Faizal, L., dan Sunarjito. (2017): Peta Sumber dan Bahaya Gempa Indonesia Tahun 2017, Pusat Penelitian dan Pengembangan Perumahan dan Permukiman, Badan Penelitian dan Pengembangan, Kementrian Pekerjaan Umum dan Perumahan Rakyat Republik Indonesia.

Kanai, K. dan Tanaka, T. (1961): On microtremors VIII, Bulletin of Earthquake Research Institute, University of Tokyo, JAPAN, 39, 99-114.

Kawase, H., Nagashima, F., Nakano, K., dan Mori, Y. (2018): Direct evaluation of S-wave amplification factors from microtremor H/V ratios: Double empirical corrections to "Naka- mura" method, Soil Dynamics and Earthquake Engineering, in press.

Konno, K. dan Ohmachi, T. (1998): Ground-Motion Characteristics Estimated from Spectral Ratio between Horizontal and Vertical Components of Microtremor, Bull. Seism. Soc. Am., 88(1), 228-241.

Kramer, S. L. (1996): Geotechnical Earthquake Engineering, Prentice-Hall, United States.

Lachet, C. dan Bard, P.Y. (1994): Numerical and Theoretical Investigations on the Possibilities and Limitations of Nakamura's Technique, J. Phys. Earth, 42, 377-397.

Mucciarelli, M. dan Monachesi, G. (1999): The bovec (slovenia) earthquake, apful 1998: preliminary quantitative association among damage, ground motion amplification and building frequencies, Journal of Earthquake Engineering, 3(3), 317-327. Journal of Earthquake Engineering, 3(3), 317-327.

Mucciarelli, M., Gallipoli, M. R., dan Arcieri, M. (2003): The Stability of the Horizontal-to-Vertical Spectral Ratio of Triggered Noise and Earthquake Recordings, Bulletin of the Seismological Society of America, 93(3), 1407-1412.

Nakamura, Y. (1989): A Method for Dynamic Characteristics Estimation of Subsurface using Microtremor on the Ground Surface, Quarterly Report of Railway Technical Research Institute (RTRI), 30, No.1

Nakamura, Y. (1996): Real Time Information Systems for Seismic Hazards Mitigation UrEDAS, HERAS and PIC, Quarterly Report of RTRI, 37, No. 3, 112-127.

Nakamura, Y. (1997): Seismic Vulnerability Indices for Ground and Structures Using Microtremor. World Congress on Railway Research.

Nakamura, Y. (2008): On the H/V Spectrum, The 14th World Conference on Earthquake Engineering. Nogoshi, M. and Igarashi, T. (1971): On the Amplitude Characteristics of Microtremor, Jour. Seism. Soc. Japan, 24, 26-40.

Okada, H. (2003): The Microtremor Survey Method, SEG.

Satoh, T., Kawase, H., dan Matsushima, S. (2001): Differences Between Site Characteristics Obtained from Microtremors, S-waves, P-waves, and Codas, Bulletin of the Seismological Society of America, 91(2), 313-334.

Shearer, P. M. (2009): Introduction to Seismology (2nd edition), Cambridge University Press, United Kingdom.

Van der Werff, W. (1996): Variation in forearc basin development along the Sunda Arc, Indonesia. Journal of Southeast Asian Earth Sciences, 14(5), 331-349.

Wafid, M., Sugiyanto, Pramudyo, T., dan Sarwondo. (2014): Resume Hasil Kegiatan Pemetaan Geologi Teknk Pulau Lombok Sekala 1:250.000, Pusat Sumber Daya Air Tanah dan Geologi Lingkungan, Badan Geologi, Kementrian Energi dan Sumber Daya Mineral Republik Indonesia. 